\title{
Persepsi Penjaga Perlintasan Kereta Terhadap Shift Jaga Di Masa Pandemi Covid-19 Pada Daop 1 Jakarta
}

\section{Perception of Train Crossing Guards Against Shifts During the Covid-19 Pandemic in Daop 1 Jakarta}

\author{
Dhina Setyo Oktaria \\ Politeknik Perkeretaapian Indonesia Madiun \\ dhina@ppi.ac.id
}

\begin{abstract}
This study discusses about train traffic and guard shifts in the covid-19 pandemic era whether it affects the perception of the train crossing guard (PJL) performance in the work area. This reseach used quantitative and qualitative method where the questionnaire distributed to the train crossing guard (PJL) in the working area of Daop 1 Jakarta. The result of the study showed that Partial t test of calculated values and tables then the value $t$ calculate > t table where the guard shift (X2) gives a positive influence on perception $(Y)$, while train traffic $(X 1)$ has no influence on perception $(Y)$. Simultaneous $F$ test if the value of $F$ calculates $>F$ where $F$ calculates $=15,683$ is greater than $F$ table 3.04 meaning that train traffic (X1) and guard shift (X2) simultaneously affect perception $(Y)$ with a value of $14.4 \%$.
\end{abstract}

Keywords $\quad$ : railroad crossings; shift watch; perception of the guard

\begin{abstract}
ABSTRAK
Tujuan penelitian ini tentang lalu-lintas kereta api dan shift jaga di era pandemik covid-19 pengaruh persepsi kinerja PJL di wilayah kerja. Daop 1 Jakarta. Permasalahan pada penelitian ini adalah shift jaga pada pintu perlintasan kereta api. Metode penelitian berupa metode kuantitatif dan kualitatif. Metode penelitian yang digunakan adalah regresi linear berganda. Hasil penelitian menunjukan bahwa Uji t Parsial Shift jaga memberikan pengaruh terhadap persepsi sehingga berpengaruh positif terhadap persepsi, sedangkan lalu-lintas kereta api tidak ada pengaruh terhadap persepsi. Dan uji F hitung sebesar 15,683 lebih besar daripada F tabel 3,04 artinya lalu-lintas kereta api dan shift jaga secara simultan berpengaruh terhadap persepsi (Y) dengan nilai 14,4\%.
\end{abstract}

Kata kunci : perlintasan kereta api; shift jaga; persepsi penjaga perlintasan

\section{A. Pendahuluan}

Penjaga perlintasan kereta api atau PJL sesuai dengan PM No 19 tahun 2011 tentang Sertifikasi Kecakapan Penjaga Perlintasan Kereta Api adalah orang yang menjaga perlintasan kereta api. Selain itu berdasarkan hasil penelitian di Perancis, Jepang dan Amerika menunjukkan bahwa tidak ada penemuan klaster Covid-19 di transportasi umum. Universitas Oxford juga menerbitkan jurnal yang menyatakan bahwa dengan penerapan protokol kesehatan dapat mencegah terjadinya penyebaran Covid-19 kepada pengguna jasa transportasi umum.

Berdasarkan hasil wawancara dengan beberapa Petugas Jalur Perlintasan (PJL) didapatkan jawaban bahwa setiap satu pos jalur perlintasan terdapat empat orang PJL dengan pembagian shift antara lain, shift satu yaitu dari pukul 06.00 s.d 14.00, shift 2 dari pukul 14.00 s.d 20.00 dan shift ketiga dari 
pukul 20.00 s.d 06.00, sedangkan satu petugas PJL lainnya libur/off.

Permasalahan penelitian ini adalah persepsi penjaga perlintasan di masa Pendemi, dimana shift jaga terdapat 4 kali shift jaga yang memberatkan petugas jaga. Berdasarkan hal tersebut di atas, penulis ingin melakukan penelitian mengenai persepsi dari PJL terhadap perjalanan lalulintas kereta api selama masa pandemik Covid-19 apakah memberikan pengaruh atau tidak, serta apakah pergantian shift jaga memberikan pengaruh terhadap kinerja dari PJL di wilayah kerja Daop 1 Jakarta.

\section{B. Kajian Pustaka}

Berdasarkan pernyataan dari Joni Martinus selaku Vice President PT KAI bahwa berdasarkan hasil kajian dari para ahli kereta api merupakan moda transportasi yang aman digunakan selama pandemic Covid-19 dikarenakan telah menerapkan protokol yang ketat (Rahma, 2020) bahwa berdasarkan hasil kajian dari para ahli kereta api merupakan moda transportasi yang aman digunakan selama pandemic dikarenakan telah menerapkan protocol yang ketat. Selama pandemi Covid-19 terjadi perubahan jadwal terhadap kereta yang beroperasi di Indonesia. (Ryan, 2020) : 1. Kereta api berangkat dari Stasiun Gambir antara lain yaitu a) Kereta api Argo Parayangan berangkat dari stasiun Gambir menuju ke stasiun Bandung dengan jadwal berangkat tanggal 1 s.d 31 Oktober 2020 pukul 07.50 WIB; b) Kereta api Argo Dwipangga berangkat dari stasiun Gambir menuju ke stasiun Solobalapan dengan jadwal berangkat pada tanggal 1 s.d 31 Oktober 2020 pukul 08.00 WIB; c) Kereta api Argo Bromo Anggrek berangkat dari stasiun Gambir menuju ke stasiun Surabaya Turi dengan jadwal keberangkatan pada tanggal 1 s.d 31 Oktober 2020 pukul 08.15 WIB; d) Kereta api Argo Parahyangan Excellent berangkat dari stasiun Gambir menuju ke stasiun Bandung dengan jadwal keberangkatan pada tanggal 1 s.d 31 Oktober 2020 pukul 15.40 WIB; e) Kereta api Bima berangkat dari stasiun Gambir menuju ke stasiun Surabaya Gubeng dengan jadwal keberangkatan pada tanggal 1 s.d 31 Oktober 2020 pukul 16.40 WIB; f) Kereta api Argo Bromo Anggrek berangkat dari stasiun Gambir menuju ke stasiun Surabaya Turi dengan jadwal keberangkatan pada tanggal 1 s.d 31 Oktober 2020 pukul 20.30 WIB; g) Kereta api Gajayana berangkat dari stasiun Gambir menuju ke stasiun Malang dengan jadwal keberangkatan pada tanggal 2, 9, 16, 23, 30 Oktober 2020 pukul $18.00 \mathrm{WIB}$; h) Kereta api Argo Lawu berangkat dari stasiun Gambir menuju ke stasiun Solobalapan dengan jadwal keberangkatan pada tanggal 1, $2,3,5,9,10,11,12,16,23,30$ Oktober 2020 pukul 21.00 WIB; i) Kereta api Taksaka berangkat dari stasiun Gambir menuju ke stasiun Yogyakarta dengan jadwal keberangkatan pada tanggal 4, 8, 15, 22, 29 Oktober 2020 pukul 21.30 WIB. 2) Kereta api berangkat dari Stasiun Pasar Senen a) Kereta api Bengawan berangkat dari stasiun Pasar Senen menuju ke stasiun Purwosari dengan jadwal keberangkatan pada tanggal 1 s.d 31 Oktober 2020 pukul 06.30 WIB ; b) Kereta api Tegal Expres berangkat dari stasiun Pasar Senen menuju ke stasiun Tegal dengan tanggal keberangkatan pada tanggal 1 s.d 31 Oktober 2020 pukul 07.40 WIB; c) Kereta api Dharmawangsa berangkat dari stasiun Pasar Senen menuju ke stasiun Surabaya Pasar Turi dengan jadwal keberangkatan pada tanggal 3, 4, 10, 11, 17, 18, 24, 25, 31 Oktober 2020 pukul 08.25 WIB; d) Kereta api Serayu Pagi berangkat dari stasiun Pasar Senen menuju ke stasiun Purwokerto dengan tanggal keberangkatan pada 1 s.d 31 Oktober 2020 pukul 09.15 WIB; e) Kereta api Matarmaja berangkat dari stasiun Pasar Senen menuju ke stasiun Malang dengan jadwal berangkat pada tanggal 1 s.d 31 Oktober 2020 pukul 10.30 WIB; f) Kereta api Brantas berangkat dari stasiun Pasar Senen menuju ke stasiun Blitar dengan jadwal berangkat pada tanggal 2, 9, 16, 23, 30 Oktober 2020 pukul 13.30 WIB: g) Kereta api Kertajaya berangkat dari stasiun Pasar Senen menuju ke stasiun Surabaya Pasar Turi dengan jadwal berangkat pada tanggal 1 s.d 31 Oktober 
2020 pukul 14.10 WIB: h) Kereta api Jayabaya berangkat dari stasiun Pasar Senen menuju ke stasiun Malang berangkat pada tanggal 2, 8, 9, 16, 23, 30 Oktober 2020 pukul 16.55 WIB; i) Kereta api Serayu Malam berangkat dari stasiun Pasar Senen menuju ke stasiun Purwokerto dengan jadwal berangkat pada tanggal 1 s.d 31 Oktober 2020 pukul 21.25 WIB. 3. Dari Stasiun Jakarta Kota a) Kereta api Jayakarta berangkat dari stasiun Jakarta Kota menuju ke stasiun Surabaya Gubeng dengan jadwal berangkat pada tanggal 1 s.d 31 Oktober 2020 pukul 11.45 WIB.

Covid-19 diumumkan secara resmi pertama kali di Indonesia pada tanggal 2 Maret 2020. Berdasarkan peraturan yang dikeluarkan oleh Menteri Perhubungan (Publik, 2020) berupa PM No 25 Tahun 2020 tentang Pengendalian Transportasi Selama Masa Mudik Idul Fitri Tahun 1441 Hijriah Dalam Rangka Pencegahan Penyebaran Corona Virus Disease (Covid19) (Peraturan Menteri Perhubungan Republik Indonesia Nomor PM 25 Tahun 2020 Tentang Pengendalian Transportasi Selama Masa Mudik Idul Fitri Tahun 1441 Hijriah Dalam Rangka Pencegahan Penyebaran Covid-19, 2020) yang pada intinya pemerintah melarang masyarakat mudik dengan melakukan pengendalian transportasi dengan cara melakukan pembatasan penggunaan prasarana transportasi terutama untuk transportasi dengan tujuan keluar dan/atau masuk wilayah pembatasan sosial berskala besar (PSBB); zona merah penyebaran Covid19; aglomerasi yang telah ditetapkan sebagai wilayah PSBB. PM No 25 Tahun 2020 juga mengatur tentang jenis prasarana transportasi yang dilarang salah satunya adalah transportasi perkeretaapian yaitu untuk perjalanan kereta api antarkota dan perjalanan kereta api perkotaan. Persepsi adalah (Agung, 2012) pengamatan terhadap suatu obyek atau peristiwa yang kemudian akan diperoleh hasil penafsiran terhadap obyek atau peristiwa tersebut.

\section{Metode Penelitian}

Lokasi penelitian dan obyek penelitian ini adalah PJL yang bekerja di wilayah kerja Daop 1 Jakarta dengan pertimbangan bahwa Daop 1 Jakarta merupakan sentral dari lalulintas perkeretaapian di Indonesia karena hampir semua kereta api di pulau jawa berangkat atau berhenti dari Jakarta. Sedangkan untuk jenis penelitian ini berupa penelitian kuantitatif dan kualitatif. Teknik pengambilan sampel berupa Teknik NonProbability Sampling dengan teknik non random sampling dengan memakai accidental sampling yaitu memilih seluruh PJL di wilayah kerja Daop 1 Jakarta secara acak dengan menghubungi 190 orang PJL yang telah mengisi kuesioner melalui google form lewat watsapp dan melakukan wawancara singkat dengan PLJ. Tehnik analisis data terdiri dari Analisis Statistik Deskriktif, Regresi distribusi normal, Koefisien untuk uji Multikolinieritas dan VIF

\section{Hasil dan Pembahasan}

Uji validitas dilakukan untuk mengetahui kevalidan dari pertanyaan dari kuesioner. Dikarenakan jumlah responden atau sampel sebanyak PJL maka dipakai rumus :

$\mathrm{df}=\mathrm{n}-2$ dengan signifikansi $5 \%$

df $=190-2=188$, di dalam tabel $\mathrm{r}$ dengan signifikansi 5\% di peroleh angka : 0,1424 
Tabel 1 Validitas dan Reliabilitas Pertanyaan Kuesioner

\begin{tabular}{|c|c|c|c|c|}
\hline $\begin{array}{l}\mathrm{N} \\
\mathrm{o}\end{array}$ & Pertanyaan & $\begin{array}{c}\text { Person } \\
\text { Correlation }\end{array}$ & $\begin{array}{l}\text { Sig (2- } \\
\text { tailed) }\end{array}$ & $\begin{array}{l}\text { Cronbac } \\
\text { h Alpha }\end{array}$ \\
\hline 1 & $\begin{array}{c}\text { Apakah menurut anda pandemik covid-19 memberi } \\
\text { pengaruh terhadap persepsi dari PJL di wilayah kerja } \\
\text { Daop 1? }\end{array}$ & 0.761 & 0.000 & -0.036 \\
\hline 2 & $\begin{array}{l}\text { Apakah pandemik covid-19 memberi pengaruh pada } \\
\text { lalu - lintas kereta api yang lewat di wilayah kerja } \\
\text { PJL Daop } 1 \text { ? }\end{array}$ & 0.393 & 0.000 & 0.539 \\
\hline 3 & $\begin{array}{l}\text { Apakah shift kerja (shift I, Shift II, Shift III dan off) } \\
\text { selama pandemik covid-19 memberi pengaruh pada } \\
\text { PJL di wilayah kerja Daop } 1 \text { ? }\end{array}$ & 0.778 & 0.000 & 0114 \\
\hline
\end{tabular}

Pada tabel 1 di atas diperoleh data bahwa pertanyaan kuesioner valid dikarenakan untuk pertanyaan pertama nilai pearson correlation adalah $0.761>0.1424$, untuk pertanyaan kedua nilai pearson correlation adalah $1>0.1424$, dan untuk pertanyaan ketiga nilai pearson correlation adalah $1>0.1424$. Sedangkan untuk signifikansi data semua pertanyaan adalah reliabel dikarenakan untuk pertanyaan pertama nilai signifikansi adalah $0.000<$ 0.01, untuk pertanyaan kedua nilai signifikansi adalah $0.000<0.01$ dan untuk pertanyaan ketiga nilai signifikansi adalah $0.000<0.01$. Jadi uji validitas didapatkan hasil valid. Sedangkan untuk uji reliabilitas adalah untuk mengetahui konsistensi dari kuesioner. Berdasarkan tabel 1.1. di atas di dapatkan nilai $0.365<0.60$ sehingga untuk uji reliabilitas didapatkan hasil bahwa kurang reliable. Berikut disajikan tabel tentang statistik deskriktif terhadap PJL Daop 1 Jakarta.

Tabel 2 Statistik Deskriktif

\begin{tabular}{cccccc}
\hline & N & Minimum & Maximum & Mean & Std. Deviation \\
\hline Y1 & 190 & 1 & 3 & 2.69 & .576 \\
X1 & 190 & 1 & 3 & 1.82 & .415 \\
X2 & 190 & 1 & 3 & 2.18 & .415 \\
lama_bekerja & 190 & 0 & 20 & 4.67 & 2.499 \\
Umur & 190 & 18 & 47 & 29.54 & 6.515 \\
Valid N (listwise) & 190 & & & & \\
\hline
\end{tabular}

Pada tabel 2 di atas maka di dapatkan hasil bahwa lama bekerja PJL di Daop 1 Jakarta rata-rata adalah selama 4.67 tahun. Untuk umur rata-rata PJL yang bekerja di Daop 1 adalah 29.54 tahun. Sedangkan untuk persepsi dari PJL di wilayah kerja Daop 1 Jakarta selama pandemik Covid-19 ini ratarata PJL menjawab dengan skor 2.69. Untuk pertanyaan pandemik Covid-19 apakah memberi pengaruh pada lalu - lintas kereta api yang lewat di wilayah kerja PJL Daop 1
Jakarta maka jawaban atau skor rata-rata dari responden adalah 1.82. Dan terakhir untuk pertanyaan apakah shift kerja (shift 1, Shift 2, Shift 3 dan off) selama pandemik Covid19 memberi pengaruh pada PJL di wilayah kerja Daop 1 maka di peroleh jawaban atau skor rata-rata 2.18.

Model regresi dikatakan berdistribusi normal jika data ploting atau titik-titik yang menggambarkan data sesungguhnya mengikuti garis diagonal. 


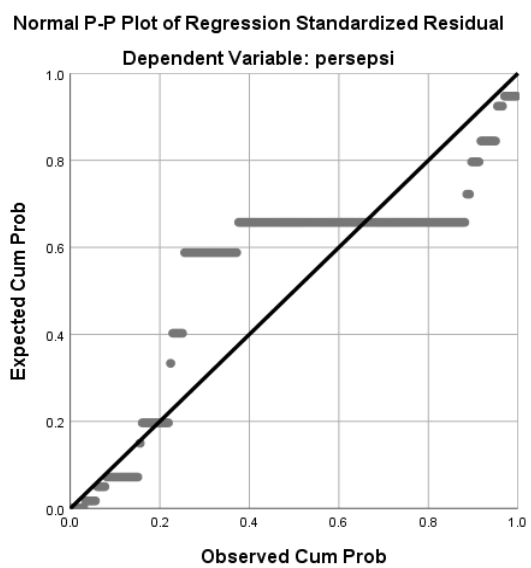

Gambar 1 Model Regresi Distribusi Normal

Pada gambar 1 di atas maka data dikatakan berdistribusi normal dikarenakan data ploting atau titik-titik yang menggambarkan data sesungguhnya mengikuti garis diagonal. Uji
Multikoliniearitas tolerance adalah dasar pengambilan keputusan uji multikolinearitas tolerance dan VIF, jika nilai tolerance > 0.0100 dan $\mathrm{VIF}<10,00$ maka tidak terjadi gejala multikolinieritas.

Tabel 3 Koefisien untuk uji Multikolinieritas dan VIF

\begin{tabular}{ccccc}
\hline \multicolumn{2}{l}{ Model } & Sig. & \multicolumn{2}{c}{ Collinearity Statistics } \\
& (Colerance & VIF \\
\hline \multirow{2}{*}{1} & shift jaga & .000 & 1.000 & 1.000 \\
& lalu-lintas KA & .296 & 1.000 & 1.000 \\
\cline { 2 - 3 }
\end{tabular}

Sumber : SPSS 25 dan diolah oleh penulis

Pada tabel 3 di atas di peroleh hasil bahwa nilai tolerance untuk shift jaga (X2) adalah 1,000, sedangkan nilai $1,000>0,0100$ sehingga tidak multikolinieritas, selain itu VIF untuk shift jaga (X2) adalah sebesar 1,000 dimana berarti $1,000<10,00$ maka tidak terjadi gelaja multikolinieritas. Sedangkan untuk lalu lintas kereta api (X1) nilai tolerance adalah 1,000 , sedangkan nilai $1,000>0,0100$ sehingga tidak multikolinieritas, selain itu VIF untuk lalulintas kereta api (X1) adalah 1,000, sedangkan nilai $1,000>0,0100$ sehingga tidak multikolinieritas. Sehingga syarat untuk tidak adanya multikolinieritas terpenuhi.

Dasar pengambilan keputusan dalam uji heteroskedastisitas adalah bila tidak ada pola yang jelas berupa bergelombang, melebar dan kemudian menyempit maka pada gambar scatterplots, serta titik-titik tersebut akan menyebar di atas dan di bawah angka 0 pada sumbu Y. 


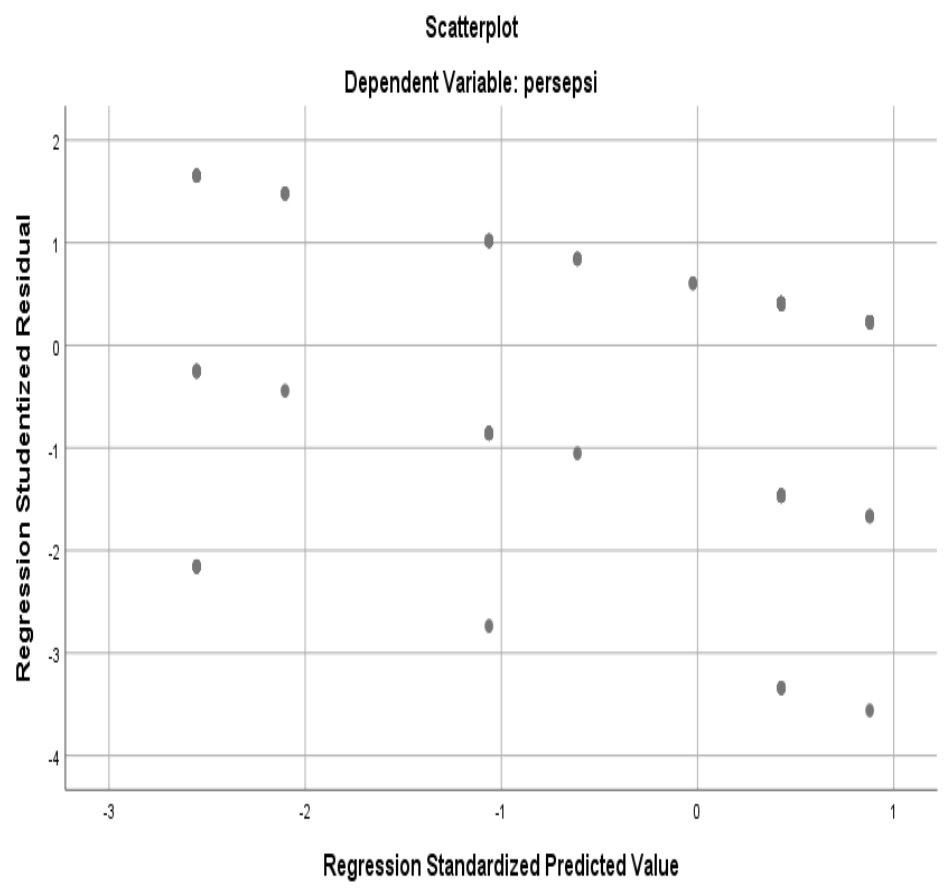

Gambar 2 Scatterplots

Pada gambar 2 di atas maka ditemukan bahwa scatterplots, serta titiktitiknya menyebar di atas dan di bawah angka 0 pada sumbu $\mathrm{Y}$ dan juga tidak ditemukan titik-titik yang berupa gelombang, melebar dan kemudian menyempit, sehingga heteroskedastisitas terpenuhi. Dasar pengambilan keputusan uji autokorelasi Durbin Watson berdasarkan pendapat dari (Ghozali, 2016) adalah dengan tidak adanya gejala autokorelasi, jika nilai Durbin Watson terletak antara du sampai dengan (4-du).

Tabel 4 Durbin Watson

\begin{tabular}{|c|c|c|c|c|c|}
\hline Model & $\mathrm{R}$ & R Square & Adjusted R Square & $\begin{array}{l}\text { Std. Error of the } \\
\text { Estimate }\end{array}$ & Durbin-Watson \\
\hline 1 & $.379^{\mathrm{a}}$ & .144 & .134 & .536 & 2.062 \\
\hline \multicolumn{6}{|c|}{$\begin{array}{l}\text { a. Predictors: (Constant), lalu-lintas KA, shift jaga } \\
\text { b. Dependent Variable: persepsi }\end{array}$} \\
\hline
\end{tabular}

Sumber : SPSS 25 dan diolah oleh penulis

Pada tabel 4 di atas maka nilai du dicari pada distribusi nilai tabel Durbin Watson. Dengan rumus bahwa nilai Du < Durbin Watson < 4-du. Maka di dapatkan bahwa nilai du dicari pada distribusi nilai tabel Durbin Watson berdasarkan k (2) dan N (190) dengan signifikansi 5\%. Maka nilai du di dapat dari tabel distribusi Durbin Watson dengan nilai signifikansi 0,005 dan k adalah 2 pada garis $\mathrm{N}$ adalah 190 diperoleh nilai 1.7838. Sedangkan untuk nilai Durbin Watson sesuai tabel adalah 2,062. Dan untuk nilai 4 -du maka 4- 1,7838 = 2,2162. Sehingga sesuai rumus $\mathrm{Du}<$ Durbin Watson $<4$-du $=1.7838<2,062<2,2162$, sehingga dapat disimpulkan bahwa tidak ada gejala autokorelasi.

Adapun dasar pengambilan keputusan untuk uji t Parsial (regresi linier berganda) berdasarkan nilai signifikansi, menurut Imam Ghozali (2013 : 101) jika nilai sig $<0,05$ maka artinya variabel independent (X1 dan $\mathrm{X} 2)$ secara parsial berpengaruh terhadap variabel dependent $(Y)$. 
Tabel 5 Koefisien

\begin{tabular}{ccccc}
\hline & \multirow{2}{*}{ Model } & Sig. & \multicolumn{2}{c}{ Collinearity Statistics } \\
& Tolerance & VIF \\
\hline \multirow{4}{*}{1} & (Constant) & .000 & & \\
& shift jaga & .000 & 1.000 & 1.000 \\
& lalu-lintas KA & .296 & 1.000 & 1.000 \\
\cline { 2 - 3 }
\end{tabular}

Sumber : SPSS 25 dan diolah oleh penulis

Pada tabel 5 di atas maka dapat disimpulkan bahwa Shift jaga (X2) mempunyai nilai 0,000 , sedangkan nilai signifikansi adalah 0,05 maka sesuai dengan rumus bahwa jika nilai sig $<0,05$ dimana $0,000<0,05$ maka shift jaga (X2) memberikan pengaruh terhadap persepsi (Y). Kemudian untuk lalu lintas kereta api (X1) mempunyai nilai 0,296 sedangkan nilai signifikansi adalah 0,05 maka sesuai dengan rumus bahwa jika nilai sig > 0,05 dimana 0,296>0,05 maka lalu-lintas kereta api (X1) tidak memberikan pengaruh terhadap persepsi (Y).
Adapun dasar pengambilan keputusan uji t Parsial (regresi linier berganda) berdasarkan nilai hitung dan tabel maka menurut V wiratna Sujarweni (2014: 155) jika nilai $\mathrm{t}$ hitung $>\mathrm{t}$ tabel maka artinya variabel independent (X1 dan X2) secara parsial berpengaruh terhadap variabel dependent $\mathrm{Y}$. Dengan rumus mencari t tabel $=\alpha / 2: \mathrm{n}-\mathrm{k}-1)=0.05 / 2: 190-2-1=0,025:$ 187, Dimana nilai dari $\mathrm{t}$ tabel dengan signifikansi 0,025 di angka 187 adalah 1,97273 .

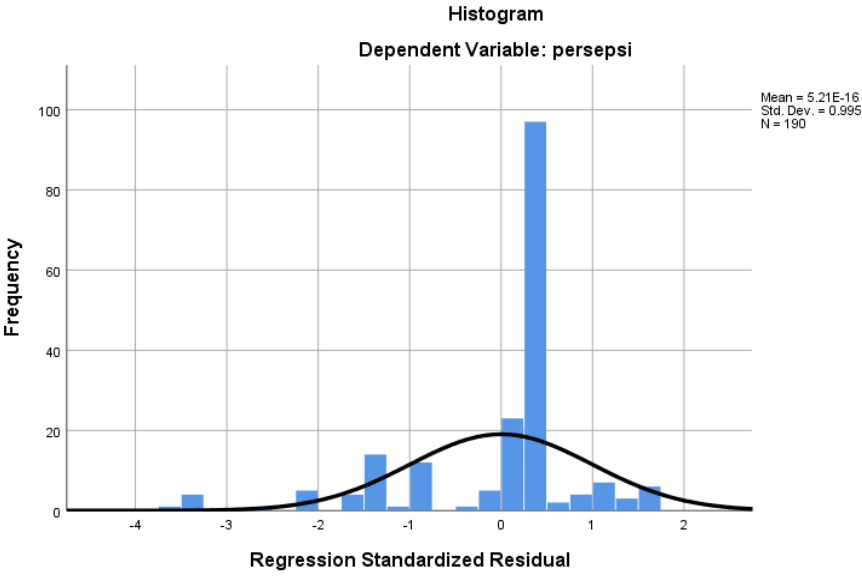

Gambar 3 Histogram

Pada gambar 3 di atas maka diperoleh hasil bahwa shift jaga (X2) memberikan pengaruh positif terhadap persepsi (Y), sedangkan lalu-lintas kereta api (X1) tidak ada pengaruh terhadap persepsi (Y).

Adapun dasar dalam pengambilan keputusan uji $\mathrm{F}$ simultan (regresi linier berganda) berdasarkan nilai signifikansi menurut (Ghozali, 2016) jika nilai sig $<0.05$ maka artinya variabel independent $(\mathrm{X})$ secara simultan berpengaruh terhadap variabel dependent (Y). 
Tabel 6 Anova

\begin{tabular}{|c|c|c|c|c|c|c|}
\hline & Model & Sum of Squares & df & Mean Square & $\mathrm{F}$ & Sig. \\
\hline \multirow{3}{*}{1} & Regression & 9.003 & 2 & 4.502 & 15.683 & $.000^{\mathrm{b}}$ \\
\hline & Residual & 53.676 & 187 & .287 & & \\
\hline & Total & 62.679 & 189 & & & \\
\hline
\end{tabular}

Sumber : SPSS 25 dan diolah oleh penulis

Berdasarkan tabel 6 di atas maka didapatkan dasar pengambilan jika nilai sig < 0.05 maka artinya variabel independent (X) secara simultan berpengaruh terhadap variabel dependent $(\mathrm{Y})$. Dimana signifikansi $0,000<0,05$ maka dapat dikatakan bahwa artinya variabel independent yaitu lalu-lintas kereta api (X1) dan shift jaga (X2) sebagai variabel independent secara simultan berpengaruh terhadap persepsi (Y) atau variabel dependent.

Begitu pula dalam keputusan uji $\mathrm{F}$ simultan (regresi linier berganda) berdasarkan nilai hitung dan tabel. Menurut V wiratna Sujarweni (2014 : 154) jika nilai F hitung > F tabel maka artinya variabel independent $\mathrm{X}$ secara simultan berpengaruh terhadap variabel dependant (Y). Adapun Rumus mencari $\mathrm{F}$ tabel $=(\mathrm{k} ; \mathrm{n}-\mathrm{k})=(2: 190$ $2)=(2: 188)=3,04$. Sehingga $F$ hitung $=$ 15,683 lebih besar daripada $\mathrm{F}$ tabel 3,04 dan didapatkan kesimpulan bahwa uji $\mathrm{F}$ simultan artinya lalu-lintas kereta api (X1) dan shift jaga (X2) secara simultan berpengaruh terhadap persepsi (Y)

Tabel 7 Pengaruh Keseluruhan

\begin{tabular}{lccccc}
\multicolumn{5}{c}{ Model Summary $^{\mathbf{b}}$} \\
\hline Model & $\mathrm{R}$ & $\mathrm{R}$ Square & Adjusted R Square & $\begin{array}{c}\text { Std. Error of the } \\
\text { Estimate }\end{array}$ & $\begin{array}{c}\text { Durbin- } \\
\text { Watson }\end{array}$ \\
\hline 1 & $.379^{\mathrm{a}}$ & .144 & .134 & .536 & 2.062 \\
\hline a. Predictors: (Constant), lalu-lintas KA, shift jaga & & \\
b. Dependent Variable: persepsi & & & \\
Sumber : SPSS 25 dan diolah oleh penulis &
\end{tabular}

Maka didapatkan bahwa pengaruh yang diberikan variabel $X$ yaitu lalu-lintas kereta api (X1) dan shift jaga (X2) baik secara parsial maupun simultan tergadap variabel $\mathrm{Y}$ atau persepsi adalah sebanyak $\mathrm{R}$ square dibagi $100 \%$ yaitu $14,4 \%$.

Selain kuesioner dengan pertanyaan tertutup, penulis juga mengajukan beberapa pertanyaan dengan kuesioner terbuka, artinya PJL dapat memberikan jawaban bebas tidak terikat dengan jawaban multiple choice. PJL Daop 1 Jakarta hampir menjadi titik asal sekaligus tujuan akhir dari perjalanan lalulintas kereta api yang dipilih oleh pelanggan. Adapun data Daerah Operasi (Daop) di wilayah pulau jawa terdiri dari : Daop 1 Jakarta, Daop 2 Bandung, Daop 3 Cirebon, Daop 4 Semarang, Daop 5 Purwokert, Daop
6 Yogyakarta, Daop 7 Madiun, Daop 8 Surabaya dan Daop 9 Jember.

Berdasarkan data statistik deskriktif di dapat hasil bahwa untuk kinerja PJL selama pandemik Covid-19 adalah 5.8\% merasa berkurang kinerjanya, $19.5 \%$ merasa cukup kinerjanya dan sebanyak $74.7 \%$ merasa sudah maksimal kinerjanya. Berdasarkan jawaban responden dari hasil pengolahan kuesioner dengan SPSS 25 dengan uji regresi linier berganda untuk uji t Parsial (regresi linier berganda) berdasarkan nilai signifikansi dapat disimpulkan bahwa Shift jaga (X2) mempunyai nilai 0,000 , sedangkan nilai signifikansi adalah 0,05 maka sesuai dengan rumus bahwa jika nilai sig $<0,05$ dimana $0,000<0,05$ maka shift jaga $(\mathrm{X} 2)$ memberikan pengaruh terhadap persepsi (Y). 
Kemudian untuk lalu lintas kereta api (X1) mempunyai nilai 0,296 sedangkan nilai signifikansi adalah 0,05 maka sesuai dengan rumus bahwa jika nilai sig > 0,05 dimana $0,296>0,05$ maka lalu-lintas kereta api (X1) tidak memberikan pengaruh terhadap persepsi (Y). uji t Parsial (regresi linier berganda) berdasarkan nilai hitung dan tabel diperoleh hasil bahwa shift jaga (X2) memberikan pengaruh positif terhadap persepsi (Y), sedangkan lalu-lintas kereta api (X1) tidak ada pengaruh terhadap persepsi (Y).

Namun berdasarkan uji F simultan maka di dapatkan bahwa variabel independent $(\mathrm{X})$ secara simultan berpengaruh terhadap variabel dependent (Y). Dimana signifikansi $0,000<0,05$ maka dapat dikatakan bahwa artinya variabel independent yaitu lalu-lintas kereta api (X1) dan shift jaga (X2) sebagai variabel independent secara simultan berpengaruh terhadap persepsi (Y) atau variabel dependent. Begitu pula dalam keputusan uji $\mathrm{F}$ simultan (regresi linier berganda) berdasarkan nilai hitung dan tabel.sehingga $\mathrm{F}$ hitung $=15,683$ lebih besar daripada $\mathrm{F}$ tabel 3,04 dan didapatkan kesimpulan bahwa uji $\mathrm{F}$ simultan artinya lalu-lintas kereta apai atau $\mathrm{X} 1$ dan shift jaga atau X2 secara simultan berpengaruh terhadap persepsi (Y). Variabel $\mathrm{X}$ yaitu lalu-lintas kereta api atau X1 dan shift jaga atau X2 baik secara parsial maupun simultan tergadap variabel $\mathrm{Y}$ atau persepsi adalah sebanyak R square dibagi $100 \%$ yaitu $14,4 \%$.

Berdasarkan hasil di pengolahan data dan analisis tersebut maka dapat disimpulkan bahwa PJL selama pandemik Covid-19 dalam bekerja tidak terpengaruh dengan lalulintas kereta api yang melewati wilayah kerja Daop 1 Jakarta, dimana terjadi pengurangan jumlah kereta yang hampir mencapai setengahnya dibandingkan dengan hari normal sebelum adanya pandemik Covid-19 melanda di Indonesia. Walaupun tidak memberikan pengaruh secara parsial namun pada saat variabel independent lalu-lintas kereta api (X1) dan shift jaga (X2) digabung hal tersebut ternyata memberikan hasil memberikan pengaruh terhadap persepsi PJL di wilayah kerja Daop 1 Jakarta sebesar $14,4 \%$.

Sedangkan untuk shift jaga ternyata memberikan pengaruh terhadap persepsi dari PJL di wilayah Daop 1 Jakarta. Dalam satu JPL atau pos penjaga perlintasan kereta api(JPL) masing-masing terdapat empat orang PJL dimana dalam satu hari kerja terdapat tiga kali shift jaga yaitu antara dari pukul 06 s.d 14.00, shift 2 dari pukul 14.00 s.d 20.00 dan shift ketiga dari pukul 20.00 s.d 06.00, sedangkan satu petugas PJL lainnya libur/off. Hal tersebut artinya seorang PJL di dalam pos JPL dalam sehari bekerja selama 8 jam atau dapat shift jaga off. Berdasarkan penelitian sebelumnya (Febriani, 2019) didapatkan hasil bahwa analisis tingkat resiko kelelahan dilakukan menggunakan metode kualitatif dan dihitung dengan mengalikan nilai consequences dan nilai likelihood. Hasil penelitian menunjukan seluruh petugas penjaga perlintasan kereta api yang diwawancarai mengaku sering mengalami kelelahan. Gejala yang dirasakan ialah tingkat kantuk meningkat ketika bertugas shift malam, merasa bosan dengan pekerjaannya, sering memaksakan diri dengan pekerjaan, kurangnya waktu istirahat, dan gangguan tidur. Hal ini dapat disimpulkan bahwa shift jaga memberikan pengaruh terhadap persepsi dari PJL. Walaupun pada hasil akhir didapatkan hasil bahwa lalu-lintas kereta api dan shift jaga memberikan pengaruh persepsi terhadap PJL di wilayah kerja Daop 1 Jakarta hanya sebesar $14,4 \%$ namun hal tersebut tetap harus mendapatkan perhatian dikarenakan keselamatan adalah hal yang mutlak tidak bisa ditawar.

\section{E. Simpulan}

Berdasarkan hasil penelitian dan pembahasan maka di dapatkan kesimpulan dan saran sebagai berikut :

PJL di Daop 1 Jakarta rata-rata lama bekerja adalah selama 4.67 tahun dan umur rata-rata PJL adalah 29.54 tahun. Sedangkan untuk persepsi dari PJL di wilayah kerja Daop 1 Jakarta selama pandemik Covid-19 
ini rata-rata PJL menjawab dengan skor 2.69. Untuk pertanyaan pandemik Covid-19 apakah memberi pengaruh pada lalu - lintas kereta api yang lewat di wilayah kerja PJL Daop 1 Jakarta maka jawaban atau skor ratarata dari responden adalah 1.82. Dan untuk pertanyaan apakah shift kerja (shift 1, Shift 2, Shift 3 dan off) selama pandemik Covid19 memberi pengaruh sebesar 2.18.

Hasil uji regresi linier berganda untuk uji t Parsial berdasarkan nilai signifikansi shift jaga (X2) memberikan pengaruh terhadap persepsi (Y). Dan untuk lalu lintas kereta api (X1) tidak memberikan pengaruh terhadap persepsi (Y). Hasil uji t Parsial (regresi linier berganda) berdasarkan nilai hitung dan tabel diperoleh hasil bahwa shift jaga (X2) memberikan pengaruh positif terhadap persepsi (Y), sedangkan lalu-lintas kereta api (X1) tidak ada pengaruh terhadap persepsi (Y).

Hasil uji F simultan (keseluruhan) variabel independent yaitu lalu-lintas kereta api (X1) dan shift jaga (X2) sebagai variabel independent secara simultan berpengaruh terhadap persepsi (Y) atau variabel dependent. Begitu pula dalam keputusan uji F simultan (regresi linier berganda) berdasarkan nilai hitung dan tabel didapatkan kesimpulan bahwa lalu-lintas kereta api (X1) dan shift jaga (X2) secara simultan berpengaruh terhadap persepsi (Y). Variabel $\mathrm{X}$ yaitu lalu-lintas kereta api (X1) dan shift jaga (X2) baik secara parsial maupun simultan terhadap variabel (Y) atau persepsi adalah sebanyak $14,4 \%$.

\section{F. Daftar Pustaka}

Agung, W. (2012). Persepsi Siswa Kelas XI SMAN 1 Depok Sleman Terhadap Kegiatan Belajar Mengajar Pendidikan Jasmani Tahun 2010/2011.

\section{$7-22$.}

Febriani, A. (2019). Analisis Tingkat Resiko Kelelahan Kerja pada Petugas Penjaga Perlintasan Kereta A di Stasiun Kota Semarang. In Analisis Tingkat Resiko Kelelahan Kerja pada Petugas Penjaga Perlintasan Kereta A di Stasiun Kota Semarang. https://doi.org/10.22201/fq.18708404e. 2004.3.66178

Ghozali, I. (2016). Aplikasi Analisis Multivariate dengan Program IBM SPSS 23. (Edisi 8). Semarang: Badan Penerbit Universitas Diponegoro.

Peraturan Menteri Perhubungan Republik Indonesia Nomor PM 25 Tahun 2020 Tentang Pengendalian Transportasi Selama Masa Mudik Idul Fitri Tahun 1441 Hijriah Dalam Rangka Pencegahan Penyebaran Covid-19. (2020).

Publik, B. K. dan I. (2020). Kemenhub Terbitkan Permenhub Pengendalian Transportasi Mudik Idul Fitri $1441 \mathrm{H}$. Http://Dephub.Go.Id/Post/Read/Kemen hub-Terbitkan-PermenhubPengendalian-Transportasi-MudikIdul-Fitri-1441-H.

Rahma, A. (2020). KAI Klaim Kereta Api Jadi Moda Transportasi Paling Aman di Tengah Pandemi. Https://Www.Liputan6.Com/Bisnis/Rea d/4350154/Kai-Klaim-Kereta-ApiJadi-Moda-Transportasi-PalingAman-Di-Tengah-Pandemi.

Ryan, N. A. (2020, October). Jadwal KA dari Jakarta Bulan Oktober 2020, Ada 19 Kereta Api. Https://Travel.Kompas.Com/Read/202 0/10/07/192000727/Jadwal-Ka-DariJakarta-Bulan-Oktober-2020-Ada-19Kereta - Api? Page $=$ all . 